\title{
Zr-Y-U stratigraphy of the kakortokite-lujavrite sequence, southern Ilímaussaq intrusion
}

\author{
Steen Andersen, John C. Bailey and Henning Bohse
}

The kakortokite-lujavrite sequence in the southern part of the Ilimaussag intrusion has been subdivided on a number of field and hand-specimen criteria (Bohse \& Andersen, 1981). The sequence is thought to represent a single pulse of magma except for the final, volumetrically insignificant intrusion of $\mathrm{M}$-C lujavrite.

In the present work, $\mathrm{Zr}, \mathrm{Y}$ and $\mathrm{U}$ data on the kakortokite-lujavrite sequence are presented. The primary aim of the geochemical survey was to see if the field divisions could be confirmed. To this end, we analysed about 200 representative samples by reconnaissance $\mathrm{X}$-ray fluorescence (XRF) techniques for the elements $\mathrm{Zr}, \mathrm{Y}, \mathrm{Rb}, \mathrm{Sr}, \mathrm{Pb}, \mathrm{Zn}, \mathrm{Mn}, \mathrm{Fe}, \mathrm{La}$, $\mathrm{Ce}$ and $\mathrm{Nd}$. Preliminary interpretation suggested that ratios such as $\mathrm{Zr} / \mathrm{Y}$ and $\mathrm{Zr} / \mathrm{La}$ showed a progressive variation through the sequence. We subsequently re-analysed the samples by precise $X R F$ techniques for $\mathrm{Zr}, \mathrm{Y}$ and $\mathrm{U}$ and it is these values which are now presented and discussed. A limited number of lujavrites from the northwestern corner of the Ilimaussaq intrusion (Kvanefjeld) were also studied for comparison with the southern sequence.

Bohse et al. (1974) and Steenfelt \& Bohse (1975) outlined the evolution of $U$ in the kakortokite-lujavrite sequence using fission track analysis of eudialyte. They reported $U$ values from the unaltered cores of eudialyte crystals and showed that contents increased through the sequence. Altered areas along margins and cracks were found to be enriched in $\mathrm{U}$ and this effect was attributed to the influence of late magmatic or hydrothermal fluids rich in $\mathrm{U}$.

\section{Analytical techniques}

$\mathrm{Zr}, \mathrm{Y}$ and $\mathrm{U}$ were analysed by conventional XRF techniques using powder pellets. Matrix effects were controlled by measuring the Compton scatter peak from the Mo tube in an offpeak position to avoid the serious interference from $\mathrm{Nb}$ and $\mathrm{Y}$ lines. The precision for $\mathrm{Zr}$, $Y$ and $U$ at typical concentration levels is close to $\pm 1.0, \pm 1.5$ and $\pm 2.5 \%$ relative, respectively. Determined (and recommended) values ppm for the international lujavrite standard NIM-L are: Zr 10600 (11 000), Y 20.1 (?25), U 13.7 (14). Agreement between U values obtained by XRF and delayed neutron counting is good (generally within $5 \%$ relative).

\section{Results and discussion}

Table 1 presents median values for $\mathrm{Zr}, \mathrm{Y}$ and $\mathrm{U}$ in the main rock units of the kakortokitelujavrite sequence and fig. 1 plots $Z r$ versus $Y$ and $U$ for the sequence in southern Ilimaussaq.

It is apparent from fig. 1 that $\mathrm{Zr}-\mathrm{U}$ and $\mathrm{Zr}$-Y show a high degree of correlation in several of the rock units. This correlation can be equated with the varying abundance of cumulus 


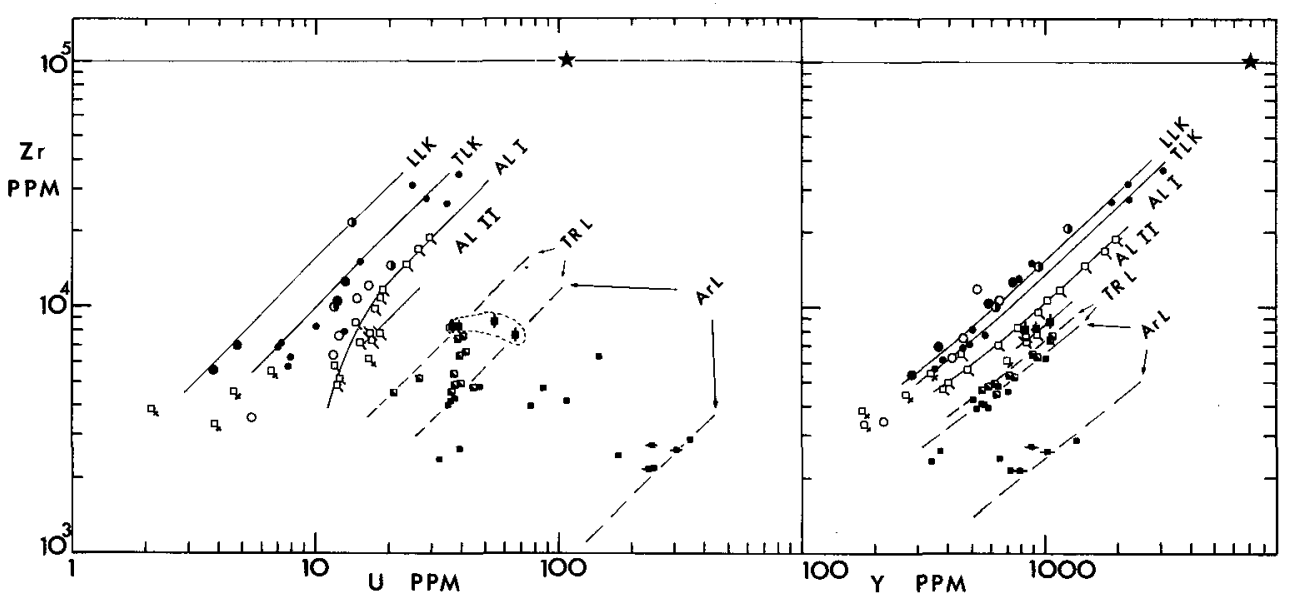

Fig. 1. Zr versus $U$ and $Y$ in the kakortokite-lujavrite sequence, southern Ilímaussaq. black, $O$ red, O white LLK lower layered kakortokite; TLK transitional layered kakortokite; $\square$ AL I aegirine lujavrite I; $\mathbf{Q}_{x}$ aegirine lujavrite I (5 samples from a different locality, not considered further); $\mathbf{Q}$ AL II aegirine lujavrite II; $\mathbf{D T R} \mathrm{L}$ transition zone lujavrites; $\mathbf{a r f v e d s o n i t e ~ l u j a v r i t e ; ~} \quad \mathrm{Nj} \mathrm{L}$ naujakasite lujavrite; M-C L medium- to coarse-grained lujavrite. $\checkmark$ eudialyte, aegirine lujavrite $\mathrm{I}$.

eudialyte. By extrapolating these eudialyte control lines to $10 \% \mathrm{Zr}$ (the $\mathrm{Zr}$ content of eudialyte), the $\mathrm{Y}$ and $\mathrm{U}$ values for eudialyte can be calculated. For the kakortokites, eudialyte values are calculated more reliably when only the data for black kakortokite are used (see below).

Although 5-10 samples may be needed to reliably establish a single $U$ content by extrapolation, this value will then be valid for all 5-10 samples. In this way, the XRF whole-rock technique quickly analyses the eudialyte in a great many samples. The technique is not limited to $\mathrm{Y}$ and $\mathrm{U}$, but can reveal the contents of all elements dominantly held by eudialyte

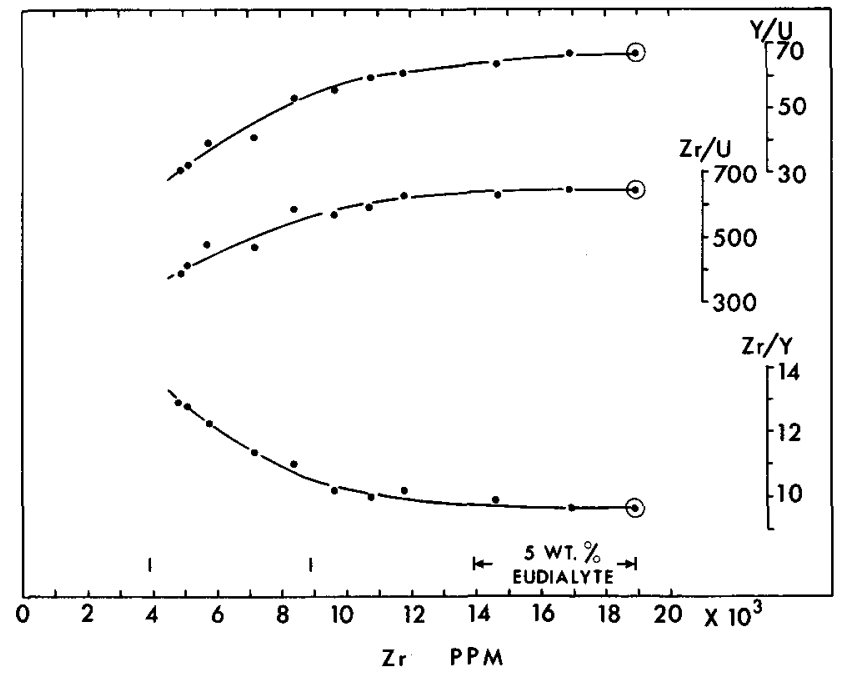

Fig. 2. $\mathrm{Zr}$ versus $\mathrm{Y} / \mathrm{U}, \mathrm{Zr} / \mathrm{U}$ and $\mathrm{Zr} / \mathrm{Y}$ across a single eudialyte cumulate horizon, bore hole 7 , aegirine lujavrite $I$. 
Table 1. Median $Z r, Y$ and $U$ contents and ratios in the kakortokite-lujavrite rocks, Ilimaussaq intrusion

\begin{tabular}{|c|c|c|c|c|c|c|c|c|}
\hline Rock u & No. & of samples & $\mathrm{zr}$ & $\mathbf{Y}$ & $u$ & $\operatorname{Zr} / \mathrm{Y}^{*}$ & $\mathbf{Y} / \mathrm{u}^{*}$ & $\mathrm{Z}_{r} / \mathrm{U}^{*}$ \\
\hline \multicolumn{9}{|c|}{ SOUTHERN ILÍMAUSSAQ } \\
\hline \multirow[t]{4}{*}{ Lower } & layered kakortokite & 12 & 8400 & 507 & 12.0 & 16.7 & 42.6 & 741 \\
\hline & - white & 5 & 7570 & 460 & 12.4 & 16.5 & 37.1 & 645 \\
\hline & - red & 3 & 14700 & 938 & 13.8 & 15.8 & 51.2 & 809 \\
\hline & - black & 4 & 8640 & 480 & 8.6 & 18.2 & 65.8 & 1200 \\
\hline \multicolumn{2}{|c|}{ Transitional layered kakortokite } & 12 & 9410 & 633 & 11.0 & 15.5 & 50.4 & 797 \\
\hline \multicolumn{2}{|c|}{ - white } & 3 & 7760 & 507 & 10.0 & 15.9 & 45.8 & 740 \\
\hline \multicolumn{2}{|r|}{- red } & 7 & 26600 & 1900 & 25.2 & 14.0 & 62.8 & 977 \\
\hline \multicolumn{2}{|c|}{ - black } & 2 & 6930 & 471 & 7.1 & 14.7 & 66.5 & 976 \\
\hline \multicolumn{2}{|c|}{ Aegirine lujavrite I } & 11 & 9640 & 944 & 17.1 & 10.2 & 55.2 & 564 \\
\hline \multicolumn{2}{|c|}{ Aegirine lujavrite Ir } & 3 & 7660 & 844 & 17.0 & 8.8 & 49.6 & 437 \\
\hline \multicolumn{2}{|c|}{ Transition zone lujavrites } & 14 & 4890 & 633 & 38.8 & 7.4 & 16.6 & 126 \\
\hline \multicolumn{2}{|c|}{ Arfvedsonite lujavrite } & 9 & 3340 & 627 & 97.5 & 6.6 & 7.4 & 48 \\
\hline \multicolumn{2}{|c|}{ Naujakasite lujavrite } & 3 & 2600 & 890 & 250 & 2.8 & 3.3 & 9.2 \\
\hline \multicolumn{2}{|c|}{ M-C lujavrite } & 4 & 8320 & 900 & 47.0 & 8.8 & 20.1 & 187 \\
\hline \multicolumn{9}{|c|}{ KYANEFJELD } \\
\hline \multicolumn{2}{|c|}{ Arfvedsonite lujavrite } & 12 & 2640 & 788 & 215 & 2.9 & 3.8 & 11 \\
\hline \multicolumn{2}{|c|}{ Naujakasite lujavrite } & 12 & 746 & 1380 & 344 & 0.56 & 3.7 & 2.3 \\
\hline \multicolumn{2}{|c|}{ M-C lujavrite } & 13 & 1880 & 558 & 180 & 3.8 & 3.2 & 12 \\
\hline \multicolumn{9}{|c|}{ MINERALS (SOUTHERN ILÍMAUSSAQ) } \\
\hline \multirow{2}{*}{\multicolumn{2}{|c|}{$\begin{array}{l}\text { Eudialyte (aegirine lujavrite I) } \\
\text { Steenstrupine (late veins, Agpat) }\end{array}$}} & 2 & 100000 & 7000 & 104 & 14.4 & 68.5 & 990 \\
\hline & & 2 & 6410 & 12700 & 4530 & 0.52 & 2.9 & 1.5 \\
\hline
\end{tabular}

* Calculated independently using Individual ratio values.

(Hf, REE and $\mathrm{Nb}, \mathrm{Ta}, \mathrm{W}$ and $\mathrm{Th}$ in some rock types). It does depend, however, on the collection of samples with a range of $\mathrm{Zr}$ contents, preferably high $\mathrm{Zr}$ contents. In our samples, there is thus some bias towards samples with high $\mathrm{Zr}, \mathrm{Y}$ and $\mathrm{U}$ contents. This is apparent when median values given in this paper are compared with median values obtained on more representative samples (Bailey et al., 1981a).

In detail, the very careful sampling in aegirine lujavrite I (bore hole 7) revealed that here, at least, the eudialyte control lines are, in fact, gently curved. This feature is brought out more clearly by plotting ratios against $\mathrm{Zr}$ (fig. 2). It is seen that ratios tend to a constant value, applicable to eudialyte, only at the highest $\mathrm{Zr}$ levels. Other phases generate significant deviations at lower $\mathrm{Zr}$ contents.

The $U$ values for eudialyte obtained by extrapolating mineral control lines or curves are in reasonable agreement with values obtained (a) by XRF analysis of separated eudialytes (Table 1) and (b) by fission track analysis. In detail, the extrapolated values tend to be higher, and this suggests that analysis of whole-rock samples includes additional $U$ beyond that deposited in primary eudialyte. This $U$ may have been deposited from U-rich intercumulus liquids and/or late magmatic or hydrothermal solutions. Some of it may be represented by the altered areas in eudialyte reported by Steenfelt \& Bohse (1975). The presence of well-defined $\mathrm{Zr}-\mathrm{U}$ curves and lines through a series of whole-rock samples indicates that $U$ was not introduced randomly into these samples by outside solutions; the $U$ probably has an 'internal, closed-system' origin. Thus, precipitation of $U$ in altered areas of eudialyte could be a closed-system autometasomatic phenomenon. On this basis, whole-rock chemistry is 
equivalent to the primary chemistry even though the rock shows alteration under the microscope and during fission track analysis.

Fig. 3 reveals that variations in $\mathrm{Zr} / \mathrm{U}$ and $\mathrm{Zr} / \mathrm{Y}$ can be used to establish a geochemical stratigraphy for the kakortokite-lujavrite sequence in southern Ilímaussaq and to characterise each rock unit. $\mathrm{Zr} / \mathrm{U}$ ratios fall from 1200 in the earliest black kakortokites to 9.2 in the final naujakasite lujavrites (Table 1). $\mathrm{Zr} / \mathrm{Y}$ ratios change by a factor of 6.5 from 18.2 in the early black kakortokites to 2.8 in the naujakasite lujavrites.

The $\mathrm{Zr} / \mathrm{U}$ and $\mathrm{Zr} / \mathrm{Y}$ ratios fall along two trends; they begin to evolve more rapidly at the boundary between kakortokite and aegirine lujavrite I. The speed of evolution is more or less constant on this logarithmic diagram both between the various lujavrite units and within the main mass of arfvedsonite lujavrite (see below for discussion).

Two deviations from these regular trends for $\mathrm{Zr} / \mathrm{U}$ and $\mathrm{Zr} / \mathrm{Y}$ require attention. Firstly, the $\mathrm{Zr} / \mathrm{U}$ ratio, and to a lesser extent the $\mathrm{Zr} / \mathrm{Y}$ ratio, for kakortokites is not a constant. In the lower layered kakortokite, median values decrease from 1200 in black kakortokite to 809 in red kakortokite to 645 in white kakortokite. Only the eudialyte control line for the black kakortokites extrapolates to the measured $\mathrm{Zr} / \mathrm{U}$ ratio of cumulus eudialyte grains. (The eudialyte contains about $40 \mathrm{ppm} \mathrm{U,} \mathrm{Zr} / \mathrm{U}$ equals 2500; Steenfelt \& Bohse, 1975). We attribute the lower $\mathrm{Zr} / \mathrm{U}$ ratios of the red and white kakortokites to the presence of a higher amount of low- $\mathrm{Zr} / \mathrm{U}$ magma trapped between the cumulus phases. This magma has crystallised forming adgrowths to the cumulus phases (including eudialyte) and also forming new interstitial phases such as minor Li-mica and rinkite (a $\mathrm{Nb}$ silicate with a low $\mathrm{Zr} / \mathrm{U}$ ratio).

Secondly, on the basis of geological and textural evidence, the $\mathrm{M}-\mathrm{C}$ lujavrite has been regarded as crystallising from the final, volatile-rich fraction of the lujavrite magmas. However, the relatively high $\mathrm{Zr} / \mathrm{U}$ and $\mathrm{Zr} / \mathrm{Y}$ ratios point to a more primitive geochemical character. Bailey et al. (1981b) attribute the relatively low U contents in Kvanefjeld M-C lujavrite to loss of U-bearing solutions. However, it is difficult to see how this could explain the relatively high $\mathrm{Zr}$ and $\mathrm{Zr} / \mathrm{Y}$ values. It is possible that the $\mathrm{M}-\mathrm{C}$ lujavrite was isolated from the main lujavrite magma chamber at a relatively early stage and largely avoided fractionation before its final-stage emplacement.

Given these irregularities, it is found that the progressive decrease of $\mathrm{Zr} / \mathrm{U}$ and $\mathrm{Zr} / \mathrm{Y}$ through the kakortokite-lujavrite sequence agrees with the sequence of formation deduced from field evidence. We anticipate that isolated bodies of lujavrite in the Ilímaussaq intrusion can be assigned to their correct position in this sequence using the above geochemical parameters.

The naujakasite lujavrite has the most evolved levels and ratios of $\mathrm{Zr}, \mathrm{Y}$ and $\mathrm{U}$ of all the lujavrites in southern Ilímaussaq and is known to occur at the highest stratigraphic level of the lujavrite sequence. It can thus be regarded as the most evolved of the lujavrite magmas.

\section{Kvanefjeld lujavrites}

The geological relations of the various Kvanefjeld lujavrites have been studied in surface exposures and drill cores (Sørensen et al., 1969, 1974). While their relative ages are well established, no attempt have been made to establish a cumulate stratigraphy.

The Kvanefjeld lujavrites follow the geochemical trends found in the southern Ilímaussaq sequence but absolute contents differ (Table 1, figs 3 and 4). Judged from their $\mathrm{Zr} / \mathrm{U}$ and $\mathrm{Zr} / \mathrm{Y}$ ratios, the 'most primitive' arfvedsonite lujavrites at Kvanefjeld correspond roughly to 

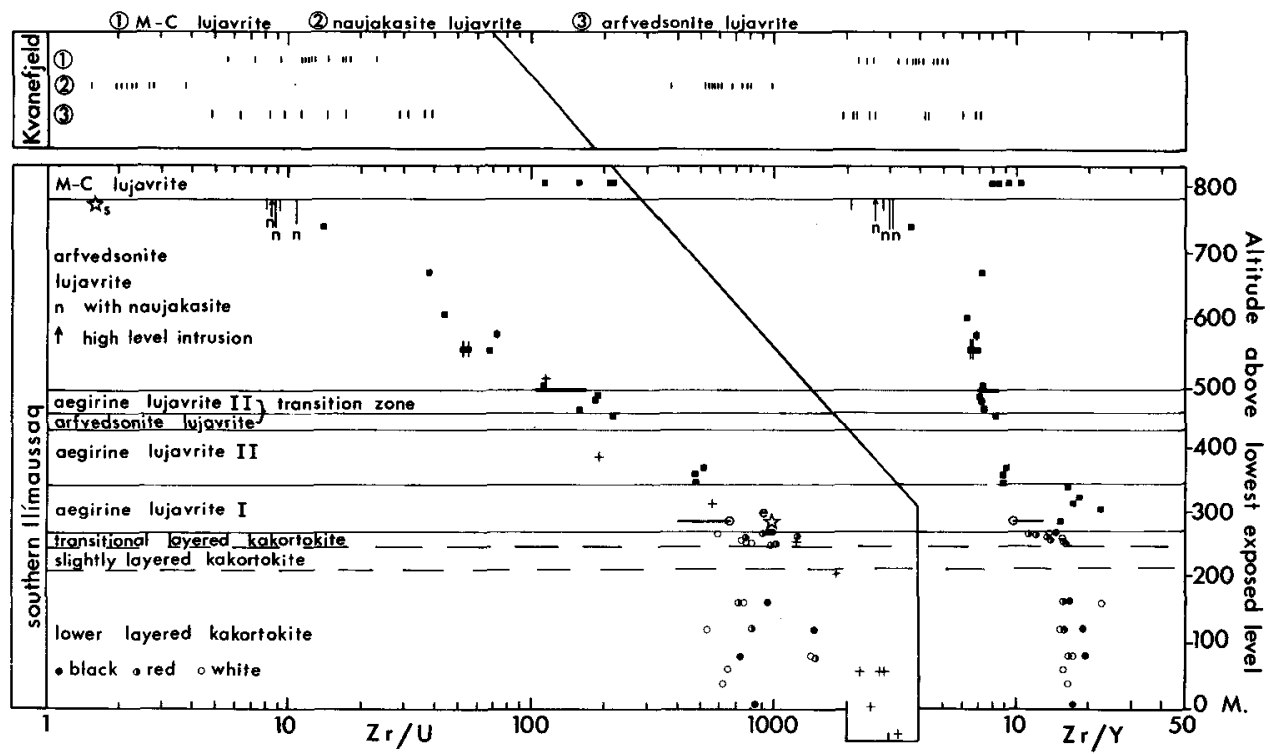

Fig. 3. $\mathrm{Zr} / \mathrm{U}$ and $\mathrm{Zr} / \mathrm{Y}$ stratigraphy in the kakortokite-lujavrite sequence, southern Ilímaussaq; and comparison with Kvanefjeld lujavrites. black, $O$ red, $O$ white kakortokites, $\square$ lujavrites (vertical bar indicates the uncertainty in stratigraphic height). $+\mathrm{Zr} / \mathrm{U}$ based on fission track analyses of eudialyte (Steenfelt $\&$ Bohse, 1975). $\$$ e, s analyses of separated eudialyte (aegirine lujavrite I) and steenstrupine (late veins). -0 values from fig. 2.

the $100 \mathrm{~m}$ stratigraphic level with the arfvedsonite lujavrite sequence from southern Ilimaussaq (fig. 4). They evolve beyond the highest, $290 \mathrm{~m}$, level of the southern sequence. The naujakasite lujavrites have the lowest $\mathrm{Zr} / \mathrm{U}$ and $\mathrm{Zr} / \mathrm{Y}$ ratios among the Kvanefjeld lujavrites and, by analogy with the southern sequence, may represent the most fractionated of the Kvanefjeld lujavrites. The M-C lujavrite, as in the southern sequence, is characterised by relatively high $\mathrm{Zr}, \mathrm{Zr} / \mathrm{U}$ and $\mathrm{Zr} / \mathrm{Y}$ values (see above).

These features suggest that the Kvanefjeld lujavrites underwent an independent, more prolonged, fractionation in an isolated magma chamber. The fractionation mechanism, however, was similar in the two chambers.

\section{Origin of $\mathbf{Z r} / \mathbf{U}$ and $\mathbf{Z r} / \mathbf{Y}$ stratigraphic trends}

Fig. 3 indicates that the stratigraphic trend for $\mathrm{Zr} / \mathrm{U}$, and to a lesser extent for $\mathrm{Zr} / \mathrm{Y}$, can be divided into two parts. The earliest part of the sequence shows little change but there is a steady decrease in the later part. The changeover cannot be located exactly at the moment but could well be at the boundary between kakortokite and lujavrite.

This boundary correlates with a number of geologic and petrologic features. The kakortokites formed under relatively quiet, regular conditions probably across the whole floor of the intrusion. Excellent gravity sorting of cumulus phases points to sinking through a wide vertical interval. In contrast, even the earliest lujavrites can be in contact with the overlying roof rocks and contain a high percentage of roof and wall xenoliths. There are local intrusive and flowage features, fracturing and bending of crystals and late to post-magmatic shearing. 


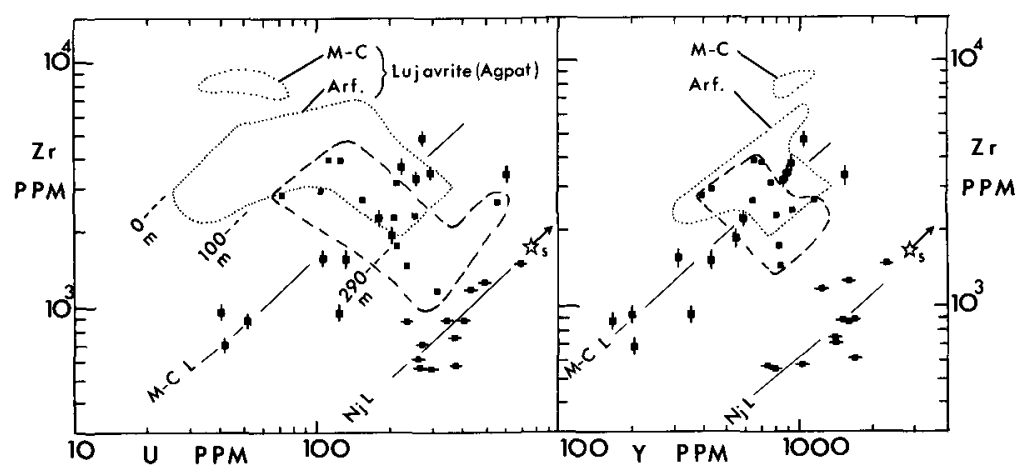

Fig. 4. $\mathrm{Zr}$ versus $\mathrm{U}$ and $\mathrm{Y}$ in Kvanefjeld lujavrites. Symbols as in fig. 1. The star with arrow points towards the composition of steenstrupine. Stratigraphic levels within arfvedsonite lujavrite from southern Ilímaussaq are indicated.

The lujavrites are thought to be poorly sorted mushes and partial cumulates which closely approach liquid compositions at higher levels. Cumulus aegirine suggests low $\mathrm{H}_{2} \mathrm{O}-\mathrm{HF}$ activity but high oxygen activity. Grain sizes decrease upwards throughout the kakortokitelujavrite sequence.

These features suggest that the appearance of lujavrite is related to a major roof subsidence and fragmentation and to the development of sub-chambers with a small vertical interval. Some magma may have flown out from the margins of the main, conformably crystallising chambers and intruded adjacent rocks. More open, oxidising conditions with a decrease in the activity of $\mathrm{H}_{2} \mathrm{O}$ and $\mathrm{HF}$, and accelerated cooling of these small chambers, may have occurred.

The kakortokite-lujavrite boundary thus marks a major change in the physical conditions of crystallization. Is this physical change also responsible for the changes in $\mathrm{Zr} / \mathrm{U}$ and $\mathrm{Zr} / \mathrm{Y}$ stratigraphic trends?

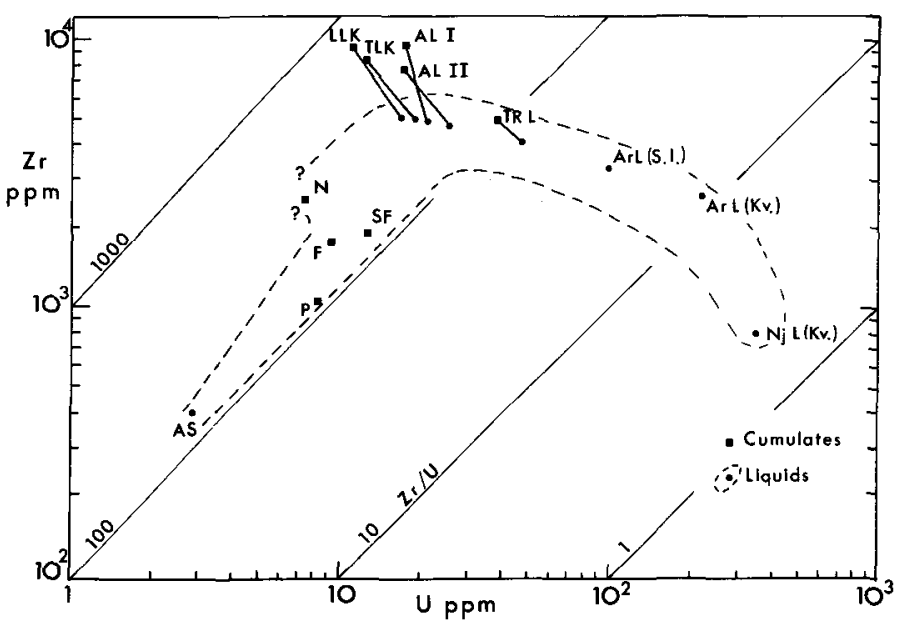

Fig. 5. Theoretical $\mathrm{Zr}-\mathrm{U}$ evolution for Ilímaussaq cumulates and liquids. Source of data: Gerasimovsky (1969), Bailey et al. (1978; this volume $\mathrm{a}, \mathrm{b}$ ) and this $\mathrm{pa}$ per. AS augite syenite, $P$ pulaskite, $F$ foyaite, $S F$ sodalite foyaite, $\mathrm{N}$ naujaite. Lujavrite abbreviations as in fig. 1 (S.I. southern Ilímaussaq, $\mathrm{Kv}$. Kvanefjeld). 
(1) Changes in partition coefficients. During fractionation of kakortokite and lujavrite, the bulk partition coefficients for $\mathrm{Zr}$ and $\mathrm{U}$ are largely determined by eudialyte. $\mathrm{D}_{\text {eud }}^{\mathrm{Zr}}$ increases as the $\mathrm{Zr}$ contents of the magma decrease (fig. 5). $\mathrm{D}_{\text {eud }}^{\mathrm{U}}$ also appears to increase: $\mathrm{U}$ contents of eudialytes from lower layered kakortokite to arfvedsonite lujavrite increase more rapidly $(\times 22)$ than $U$ contents in whole-rocks $(\times 8)$ or postulated magmas $(\times 4)$ (fig. 5). (Increasing $\mathrm{D}_{\text {eud }}^{\mathrm{U}}$ may reflect break-up of complex $\mathrm{U}$ ions in the melt and the greater availability of free $U$ ions which can enter eudialyte). We estimate that $D_{\text {eud }}^{\mathrm{Zr} U \mathrm{U}}$ probably decreases from about 2.0 to 1.2 and bulk partition coefficients show a similar trend. These estimates suggest that residual magmas and derivative (cumulate) rocks will show a decrease in $\mathrm{Zr} / \mathrm{U}$ ratios but that the ratio will decrease more slowly in the later stages. This is opposite to the observed trend.

(2) Diminished volume of magma chambers. If the appearance of lujavrite is related to roof subsidence and the development of smaller, possibly isolated, magma chambers then subsequent fractionation will proceed at a more rapid rate. If the volume diminished enough (e.g. $50 \%$ or more), this effect could override the trend discussed in (1).

(3) Changing character of analysed whole-rocks. In the kakortokites, efficient separation of cumulus phases (high $\mathrm{Zr} / \mathrm{U}$ ratios) from coexisting magma (lower $\mathrm{Zr} / \mathrm{U}$ ratios) produced cumulate rocks with high $\mathrm{Zr} / \mathrm{U}$ ratios. In the overlying lujavrites, however, the decreased vertical interval for crystal settling and the mush-like character of the magmas lead to an inefficient separation of cumulus phases and the formation of partial cumulates which more closely approached the relatively low $\mathrm{Zr} / \mathrm{U}$ ratio of the magma. The approach becomes very close in the highest level arfvedsonite and naujakasite lujavrites which are probably similar in composition to their parent liquids.

We conclude that mechanisms (2) and (3) prevailed over mechanism (1) and that the postulated change in physical conditions is capable of explaining the observed chemical changes. Thus, the diminished volume and vertical dimension of the lujavrite magma chamber lead to a more rapid fractionation and to the appearance of poorly sorted partial cumulates.

\section{Zr-U evolution of Ilímaussaq liquids}

In fig. 5 we schematically and speculatively present the evolution of $\mathrm{Zr}$ and $\mathrm{U}$ in the cumulate rocks and coexisting magmas of the Ilímaussaq intrusion. The control points for this diagram are limited:

(1) The augite syenite and the earliest roof rocks of the internal, layered sequence (pulaskite, foyaite and sodalite foyaite) show a steady increase of $\mathrm{Zr}$ and $\mathrm{U}$ which is consistent with the process of fractional crystallization. At this stage virtually no $\mathrm{Zr}$ or $\mathrm{U}$ is removed in the fractionating phases.

(2) The sodalite-rich roof cumulates (naujaite) show unusually low $U$ and high $\mathrm{Zr} / \mathrm{U}$ values. See Steenfelt \& Bohse (1975).

(3) Magma coexisting with kakortokite has a lower $\mathrm{Zr}$, higher $\mathrm{U}$ and lower $\mathrm{Zr} / \mathrm{U}$ ratio than the bulk kakortokite separate. A suggested magma composition is marked in fig. 5. Supporting this suggestion is the analysis of a 'microkakortokite' dyke ( $\mathrm{Zr} 4850 \mathrm{ppm}, \mathrm{U} 19.5 \mathrm{ppm}$; 
Larsen \& Steenfelt, 1974) which has been regarded as close to an Ilímaussaq liquid in composition.

(4) The final lujavrites (arfvedsonite and naujakasite lujavrites from southern Ilímaussaq and Kvanefjeld) are considered to be close to liquids in composition.

(5) Between controls (3) and (4) we envisage a series of liquids with steadily decreasing $\mathrm{Zr}$ and $\mathrm{Zr} / \mathrm{U}$ and rising $\mathrm{U}$ values.

Fig. 5 essentially reveals a steady increase in $\mathrm{U}$ but a rise and fall in $\mathrm{Zr}$ contents. This can be integrated with the appearance of Zr-rich eudialyte in the 'intermediate' kakortokite stage of the evolution and the steady exhaustion of the succeeding melts in Zr. U only enters eudialyte in limited amounts and continued to concentrate into the final economic lujavrites at Kvanefjeld.

Acknowledgement. The Danish Natural Science Research Council (SNF) supported the X-ray fluorescence analytical programme.

\section{References}

Bailey, J. C., Gwozdz, R., Rose-Hansen, J. \& Sørensen, H. 1978: Preliminary geochemical work on the Ilímaussaq alkaline intrusion, South Greenland. Rapp. Grønlands geol. Unders. 90, 75-79.

Bailey, J. C., Bohse, H: \& Demina, A. 1981a: Extension of Zr-REE-Nb resources at Kangerdluarssuk Ilímaussaq intrusion. Rapp. Grønlands geol. Unders. 103 (this volume).

Bailey, J. C., Rose-Hansen, J., Løvborg, L. \& Sørensen, H. 1981b: Evolution of Th and U whole-rock contents in the Ilímaussaq intrusion. Rapp. Gronlands geol. Unders. 103 (this volume).

Bohse, H. \& Andersen, S. 1981: Review of the stratigraphic divisions of the kakortokite and lujavrite in southern Ilímaussaq. Rapp. Grønlands geol. Unders. 103 (this volume).

Bohse, H., Rose-Hansen, J., Sørensen, H., Steenfelt, A., Løvborg, L. \& Kunzendorf, H. 1974: On the behaviour of uranium during crystallization of magmas - with special emphasis on alkaline magmas. In: Formation of Uranium Ore Deposits, p. 49-60. Vienna: International Atomic Energy Agency.

Gerasimovsky, V. I. 1969: Geochemistry of the Ilimaussaq alkaline massif (in Russian). Moskva: Nauka, 174 pp.

Larsen, L. M. \& Steenfelt, A. 1974: Alkali loss and retention in an iron-rich peralkaline phonolite dyke from the Gardar province, south Greenland. Lithos 7, 81-90.

Steenfelt, A. \& Bohse, H. 1975: Variation in the content of uranium in eudialyte from the differentiated alkaline Ilímaussaq intrusion, south Greenland. Lithos 8, 39-45.

Sørensen, H., Hansen, J. \& Bondesen, E. 1969: Preliminary account of the geology of the Kvanefjeld area of the Ilímaussaq intrusion, South Greenland. Rapp. Grønlands geol. Unders. 18, $40 \mathrm{pp}$.

Sørensen, H., Rose-Hansen, J., Nielsen, B. L., Løvborg, L., Sørensen, E. \& Lundgaard, T. 1974: The uranium deposit at Kvanefjeld, the Ilímaussaq intrusion, South Greenland. Rapp. Grønlands geol. Unders. 60, $54 \mathrm{pp}$.

Institut for Petrologi, University of Copenhagen, $\emptyset$ ster Voldgade 10,

DK-1350 Copenhagen K. 